\title{
Historical Perspective on the Health Transformation in Turkey
}

\author{
Nurşen AYDIN
}

\begin{abstract}
Turkey has undertaken major reforms since 2003 to transform and improve its healthcare system and health outcomes. This historical evaluation aims to shares experiences gained from Turkey's Health Transformation Program (HTP) with scholars, policymakers, and the public. Until today from the establishment of the Republic of Turkey, the legal regulations and practices for improving health services have been explained, and the results have been evaluated from a historical perspective. Our review shows that HTP has created a model that achieved goals for universal health insurance, family medicine, access to health services, and service quality. HTP increased access to health services and affected service quality. However, it has not achieved full decentralization of secondary and tertiary healthcare providers. Public hospital associations and public health directorates were reunited under the Provincial Health Directorate. It is stated that various factors such as having three different bodies in administration, problems with the competence of appointed managers, unsettled organizational structure, more than one managers being appointed and frequent changes in office, dissatisfaction of healthcare workers, and problems in communication and coordination. Countries wishing to reform may be more productive in implementing decentralization considering in their own circumstances.
\end{abstract}

Keywords: Health policy; health care reform; public policy.

\section{öz}

\section{Türkiye'de Sağlıkta Dönüşüm Üzerine Tarihsel Bakış}

Türkiye, sağlık sistemini ve sağlık sonuçlarını dönüştürmek ve iyileştirmek için 2003 yılından bu yana büyük reformlar gerçekleştirmiştir. Bu tarihsel değerlendirme, Türkiye'nin Sağlıkta Dönüşüm Programı’ndan (SDP) elde edilen deneyimleri akademisyenler, politika yapıcılar ve halkla paylaşmayı amaçlamaktadır. Türkiye Cumhuriyeti'nin kuruluşundan bugüne kadar sağlık hizmetlerinin iyileştirilmesine yönelik yasal düzenlemeler ve uygulamalar anlatılmış ve tarihsel bir bakış açısıyla değerlendirilmiştir. İncelememiz, SDP'nin genel sağlık sigortası, aile hekimliği, sağlık hizmetlerine erişim ve hizmet kalitesi için hedeflere ulaşan bir model oluşturduğunu göstermektedir. SDP sağlik hizmetlerine erişimi artırdı ve hizmet kalitesini etkiledi. Ancak, ikinci ve üçüncü basamak sağlık hizmeti sunan kurumların adem-î merkeziyetçiliği tam olarak sağlanamamıştır. Kamu Hastane Birlikleri ve Halk Sağlığı Müdürlükleri, İl Sağlık Müdürlüğü bünyesinde yeniden birleştirilmiştir. Bunda, yönetimde üç farklı organın olması, atanan yöneticilerin yetkinliği ile ilgili sorunlar, kararsız organizasyon yapısı, birden fazla yöneticinin atanması ve sık sık görev değişikliği, sağlık çalışanlarının memnuniyetsizliği, koordinasyon sorunları gibi faktörlerin etkili olduğu belirtilmiştir. Reform yapmak isteyen ülkelerin, adem-î merkeziyetçiliği kendi koşullarına göre uygulamaları daha verimli olabilir.

Anahtar Kelimeler: Sağlık politikaları; sağlık reformu; kamu politikası.

\section{INTRODUCTION}

There is a strong relationship between health policy and health outcomes. In Turkey for the improvement of the welfare state and health status of individuals; health policies and practices have undergone numerous changes and transformations in line with globalization and technological developments. The country's Health Transformation Program (HTP) has achieved comprehensive reforms that have been discussed nationally and internationally for 20 years. Numerous journal articles and books about Turkey's HTP have been published, and it was shown so much

Izmir Provincial Health Directorate, Bornova District Health Directorate, Izmir, Turkey 
interest to the program. It is necessary to review the last point from a historical perspective (1). This briefing evaluates those efforts and shares lessons learned. At first examines the history of Turkey's healthcare policies and then evaluates the successes and shortcomings of HTP.

\section{HISTORICAL BACKGROUND}

Turkey has made numerous reforms to improve its health services. Health policies in the Turkish Republic have been shaped by conditions of the period and the influence of international organizations. These reforms were examined to divide into five periods.

\section{Between 1920 and 1946}

The Ministry of Health $(\mathrm{MoH})$ was established in 1920 after the opening of the Grand National Assembly of Turkey. This period was marked by efforts to heal wounds from the War of Independence. The foundations of Turkish health policy date back to 1946 after the establishment of the Republic. The Constitution of 1921 proclaimed that healthcare services should be centralized, that preventive medicine was the duty of the central government, and that therapeutic medicine was the duty of local authorities $(2,3)$.

Health care services were organized as government agencies, municipal medical services, and small healthcare offices. Their priority was preventive health services, and their programs centered upon contagious diseases (malaria, tuberculosis, leprosy). Examination and treatment centers were established in many districts, and physicians were prohibited from engaging in private practice. Numune (specimen) hospitals were opened in big cities (4).

\section{Between 1946 and 1960}

Turkey's central government assumed responsibility for all health care services after 1946. The first health plan of the Republican period was approved in 1946, but it could not be implemented. The health planning initiative titled "National Health Program and Health Bank Studies" was adopted in 1954. University-affiliated medical faculties were opened in Istanbul, Ankara, and other major cities (5).

Significant progress was made with health centers, maternity hospitals, facilities for infectious diseases, and development of human resources. Rates of tuberculosisrelated deaths and infant mortality decreased significantly. In 1947 the Refik Saydam Sanitation Center was established, and production of vaccine began. The Labor Insurance Administration (LIA) was established in 1946, and the Retirement Fund was established in 1952 for public employees. Health institutions and hospitals were opened for insured workers after 1952. Laws were enacted concerning non-governmental organizations (e.g., the Turkish Medical Association) and some medical professions (e.g., nurses) (6).

\section{Between 1960 and 1980}

Law 224 on the Socialization of Health Care Services was enacted in 1961, and socialization of health services began in 1963. During this period, health houses (primary health care is provided such as health education, vaccination practices, death, birth and migration detection and monitoring), health centers, district hospitals, and provincial hospitals were integrated.

In 1963 the first five-year development plan is set as health goals. Law 554 concerning population planning was enacted in 1965, and limiting population growth became national policy. The approach of "one-way service in a wide region" was abolished, and the approach of "multifaceted service in a narrow region" was adopted (4).

\section{Between 1980 and 2003}

Article 56 of the Constitution of 1982 specifies that "general health insurance can be made" to facilitate the spread of healthcare services. In 1986 the Social Security Organization for Artisans and Self-Employed began to receive health benefits (SSOASE). In 1987 the Fundamental Law on Health Services (No. 3359) was enacted. The provision that "health care institutions are transformed into health care enterprises having a public legal entity" precipitated transforming public healthcare institutions into autonomous enterprises (5).

In 1990, the Turkish Health Sector Master Plan Study was prepared. The first and second National Health Congresses were held in 1992 and 1993, and in 1993, the National Health Policy was prepared (7).

Following enactment of Law 3816 (Green Card) in 1992, the state began to pay some health expenditures for lowincome citizens not covered by any social security institution. With its implementation, public health insurance fell under four structures: LIA, SSOASE, the Retirement Fund, and the Green Card. Consequently, different pricing (according to these four institutions) were introduced for the same health service. Since 1967, laws promoting general health insurance have been drafted seven times $(1967,1969,1971,1974,1987,1998$, and 2000) but were not enacted. Finally, Law 4447 on Social Security Reform consolidated general health insurance under one structure in $1999(8,9)$.

During the 1980s, lack of insurance coverage, geographical impediments to accessing healthcare, problems in distributing health resources, patients being transferred to private practices of physicians, or unofficial payments to suppliers and vendors necessitated healthcare reform in Turkey and throughout the World (10). The two most important health problems are the rapidly increasing costs and the lack of access to the system (11). During this period, as in Turkey, health reforms have been carried out in many countries around the world such as USA, Greece, and Italy (11-13).

In 2002, the framework for reforms was determined by the HTP. This program intended to facilitate access to healthcare, improve quality of services, strengthen planning and supervision by the $\mathrm{MoH}$, develop health information systems, ensure rational use of drugs and materials, and establish a general health insurance system $(5,14)$.

\section{3 and later}

As the most recent reform to Turkish healthcare, HTP has four important objectives (14). The first is family medicine practice. A pilot project in Düzce in 2005 was expanded nationwide in 2010 (15).

The second objective is the transition to general health insurance. The Social Security Institution Law 5502 was passed in 2006, and after establishment of the Social Security Institution, the Social Insurance and General Health Insurance Law provided that the entire Turkish 
population was covered by general health insurance (16). The social security system in Turkey was radically transformed with the enactment of the these laws (17). The third objective is to structure institutions that provide secondary and tertiary healthcare services as health enterprises. The Fundamental Law on Health Services established a legal infrastructure for transforming public healthcare institutions into healthcare enterprises. In 2011, Decree Law 663 restructured public hospitals as "autonomous" institutions within a framework of public hospital associations (14). Three public entities have been formed in Turkey's provinces: the health directorate, the general secretariat of public hospital associations, and the public health directorate. These institutions serve different and complementary functions in providing of health. The decentralization of healthcare institutions was modified in 2017 and Decree Law 694 reunited them under the Provincial Health Directorate, the general secretariat of public hospital associations, and public health directorates (Pub. L. No. 694, 2017). The provincial organizational structure of the $\mathrm{MoH}$ before and after re-centralization is as shown in Figure $1(16,18)$.

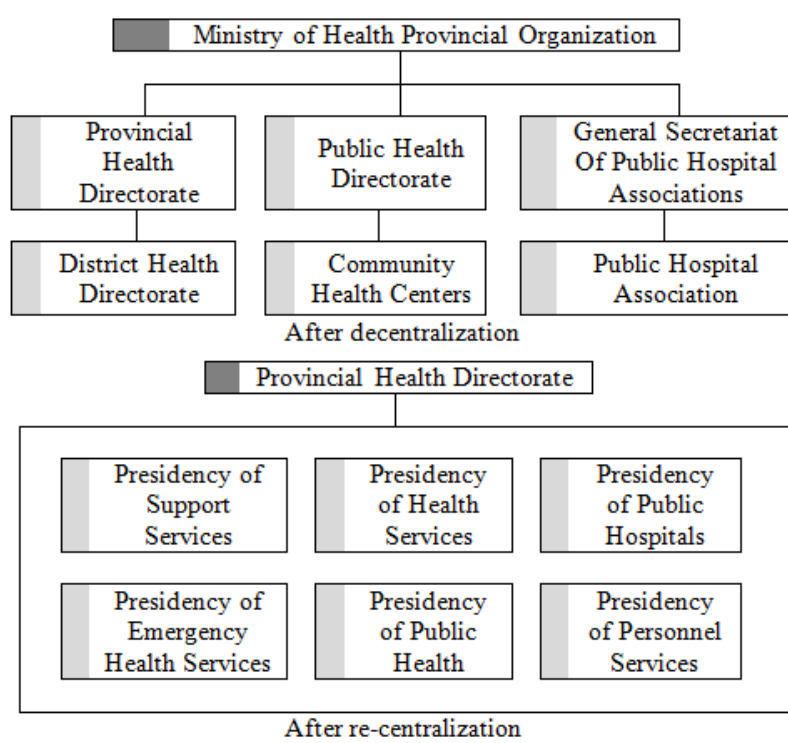

Figure 1. Ministry of Health Provincial Administration comparison

HTP's fourth objective is to establish a regulatory and supervisory role for the $\mathrm{MoH}$ (19), which was restructured by regulation in 2011. With the advent of the Presidential Government System in 2017, its structure changed radically, as did all institutions in Turkey (20).

Apart from regulations described above, HTP encompasses arrangements for health promotion, pharmaceuticals, and 112 emergency services. The valueadded tax on pharmaceuticals was reduced, and drug prices fell significantly which access to medication.

Pilot implementation of the Pharmaceutical Tracking System began in 2009 and was expanded throughout Turkey in 2010. Drug prospectuses were made more understandable (2011). The 112 emergency services were introduced throughout Turkey. Air and sea transport was added to the system, ambulances were equipped with high technology, and contributed to the service quality.

Pilot implementation of the Central Hospital Appointment System (CHAS) commenced in 2009, and it was extended nationwide in 2011. Patients began to make online appointments via CHAS.

Projects such as cancer screening (2004), combating tobacco use (2008), mental health (2008), and cardiovascular disease prevention (2011) were carried out within the scope of health promotion and preventive medicine $(3,5,8)$. During this period, innovations ranging from total quality management to home healthcare were implemented among all health services institutions. Other historical developments in the system are shown in Table $1(8,21)$.

Table 1. Other policy developments in the Turkish Health System

2003 Total quality management in public hospitals began.

2003 In 2003, a performance-based supplementary payment system was introduced in organizations affiliated with the Ministry of Health; in 2004, an individual performancebased payment system was implemented; in 2005 , corporate efficiency and quality criteria were added to the performance-based payment system.

2003 Hospitals affiliated with the Ministry of Health transitioned from wards to rooms with bathrooms and toilets.

2004 Patients received the right to choose their physicians

2004 The Health Information Communication Center (SABİM) was opened.

2004 Establishment of the National Medical Rescue Team (UMKE) was completed.

2005 LIA hospitals were transferred to the Ministry of Health

2005 A Patient Rights Unit was established in all hospitals affiliated with the Ministry of Health.

2005 The Service Quality Standards Scale was developed, and public hospitals began to be evaluated twice yearly for compliance with service quality standards.

2006 A Public-Private Partnership model was developed to finance investment in healthcare.

2007 The Social Security Institution started to publish its Health Implementation Communiqué and began to track patient information electronically.

2010 The Full Day Law was prepared for the full-time work of universities and health personnel.

2010 The Health Services at Home initiative was inaugurated to treat patients who could not come to a healthcare facility.

2010 Efforts to reduce bureaucracy and simplify administration were initiated.

2011 The White Code System was implemented to prevent violence against healthcare workers.

2012 Green Card beneficiaries were included in General Health Insurance.

2017 Employees working as subcontractors started to work as permanent workers in the Ministry of Health. (Decree Law No. 663.)

2019 The City Hospitals Project was initiated as a public-private partnership and remains ongoing. 
HTP in Turkey began to be implemented in 2003. It integrated aspects of many systems, and implemented a program of comprehensive and basic applications. A Turkish model for healthcare emerged $(22,23)$. HTP produced various outcomes, including reductions in share of out-of-pocket expenditures (10), post-implementation, unification of insurance institutions, promotion of patient rights, and the right to choose a physician, and emphasis on quality and accreditation (19).

General health insurance unified standards and norms in practice, abolishing disparities in health insurance. LIA and other hospitals were transferred to the $\mathrm{MoH}$. Healthcare services and its financing were separated from each other. All insured citizens have equal access to public healthcare services and facilities (8).

The private sector was incentivized, and some public hospitals have procured private sector services. To balance rising demand, however, restrictions have been imposed on the private sector through practices and audits to increase quality (3).

Quality management began to be implemented in all healthcare institutions. Hospitals have begun to measure healthcare quality indicators monthly. Regulations for patient and employee safety have been introduced. Inpatients now can be treated without any extra payment (except for co-payments) such as paying for drugs and material. Hospitals meet all patient needs.

Among the most important of HTP's outcomes was digitizing every stage of providing healthcare. Employees and service users have been saved from unnecessary recording, archiving, and storing of paperwork. Paper use has fallen significantly.

Turkey's basic health indicators have improved since the reform: life expectancy at birth has increased, and infant mortality rates have dropped. Turkey's basic health indicators have shown average performance compared to other upper-middle-income countries $(3,16,24-26)$.

The share of healthcare expenditures within the budget climbed regularly until 2008 and reached 12\% (27). Since 2008 it has decreased slightly and remains around $11 \%$. After 2003, prices for medicine and medical equipment generally have fallen, but overall expenditures have risen through greater use (28).

Turkish citizens have satisfied positive consequences from the transformation of healthcare. Studies that measure quality of healthcare services, access, and satisfaction with family medicine services have yielded highly positive results (29-31). The rate of satisfaction with healthcare services rose from $39.5 \%$ in 2003 to $75.9 \%$ at year-end 2011 (8). However, it has decreased relatively since 2015 , falling below the OECD average (32). On the other hand, there is a need for more studies on the satisfaction of healthcare professionals.

Moreover, international responses to HTP have been positive. The World Health Organization has highlighted the program as a success. Reports and articles on the HTP have been published by international organizations, such as the OECD, the World Bank, UNICEF, and scholars (21-23,33,34).

However, the goal of constructing secondary and tertiary healthcare institutions as "autonomous" enterprises did not meet with the desired success from 2011 to 2017, and public hospital associations and public health directorates were reunited under the Provincial Health Directorate. Several factors have undermined performance of these institutions. They include unsettled organizational structure, oversight by three disparate administrative bodies, problems in communication and coordination, appointment of more than one director, frequent changes in office, persisting effects of the central government (16), incompetence of appointees, and regional inequalities (35).

The central government has not been able to delegate its decision-making autonomy to local government, especially in the area of investments in finance, human resources management and high-tech equipment. Thus, public hospital associations became dysfunctional and failed (1).

Although Decree Law 663 sought localization of services, centralization intensified in practice. A 2014 OECD report criticized over-centralized governance in Turkey for hampering local initiatives and flexibility (21). Healthcare professionals' dissatisfaction with HTP reforms also have dampened its success (36). It was stated that the health workers employed with the new employment methods (contracted, subcontracted, flexible working etc.) introduced with the SDP were deprived of job security, the working conditions became more difficult (37), and the work peace was deteriorated due to the different wages (despite doing the same job) paid to the employees (38). It is emphasized that the new practice negatively affects working conditions such as increasing the workload of employees, insufficient education and personal development, and worsening economic and social conditions (39).

In a study, it was observed that although there was technological progress in hospitals, there was a decrease in the total factor productivity of hospitals (40). Problems threaten financial sustainability of the healthcare system and desired levels of reform. The paramount concern is escalating healthcare expenditures. Another is that healthrelated investment, notably in drugs and devices, has not reached desired levels (9).

\section{CONCLUSION}

HTP has created a model that instituted general health insurance, facilitated access to health services, and increased service quality. Key health indicators have improved, and most targets have been reached. However, decentralization of public hospitals has not proceeded as desired. Underlying these problems' rise and increase it is stated that various factors such as having three different bodies in administration, problems with the competence of appointed managers, unsettled organizational structure, more than one managers being appointed and frequent changes in office, dissatisfaction of healthcare workers, and problems in communication and coordination. Countries wishing to reform may be more productive in implementing decentralization considering in their own circumstances. To ensure financial sustainability, innovation, and research and development, investments need to be increased and efforts to combat preventable/chronic diseases should be intensified.

Authors' Contributions: Concept: N.A.; Design: N.A.; Data collecting: N.A.; Analysis and/or Interpretation: N.A.; Literature Review: N.A.; Manuscript Writing: N.A.; Critical Review: N.A. 


\section{REFERENCES}

1. Küçük A. Public hospital reform in Turkey: the "public hospital union" case (2012-2017). Int J Health Plann Manage. 2018; 33(4): e971-84.

2. OECD and World Bank. OECD reviews of health systems: Turkey. 2008. Available from: www.oecd.org/publishing/corrigenda

3. Sulku SN. Türkiye'de sağlıkta dönüşüm programı öncesi ve sonrasında sağlık hizmetlerinin sunumu, finansmanı ve sağlık harcamaları. Ankara-Turkey: Maliye Bakanlığı-Strateji Geliştirme Başkanlığg; 2011. Yayın No: 2011/414.

4. Ministry of Health. Health transformation program in Turkey and primary health care services november 2002-2008 (in celebration of the 30th year of the declaration of Alma-Ata). Akdag R, Aydin S, Buzgan T, Demirel H, Gunduz F, editors. Republic of Turkey, Ministry of Health; 2008. Health Publication No: 770.

5. Ministry of Health. Progress report: health transformation program in Turkey. Akdag R, Aydin S, Demirel H, editors. Ankara-Turkey: Republic of Turkey, Ministry of Health; 2009.

6. Akdur R. Temel kavramlar Türkiye ve Avrupa Birliği'nde durum ve Türkiye'nin birliğe uyumu. 2nd ed. Erhan Ç, editor. Ankara-Turkey; 2006.

7. Ileri H, Secer B, Ertas H. Sağlık politikası kavramı ve Türkiye'de sağlık politikalarının incelenmesi. Selcuk Univ J Soc Tech Res. 2016; 12: 176-86.

8. Ministry of Health. Türkiye'de sağlikta dönüşüm programı değerlendirme raporu (2003-2011). Akdag R, editor. Ankara-Turkey; 2012. Available from: http://sbu.saglik.gov.tr/Ekutuphane/kitaplar/SDPturk. pdf

9. TUSIAD. Charting the way forward: health care reform in Turkey. Istanbul-Turkey: TUSIAD-Turkish Industrialists' and Businessmen's Association; 2005. TUSIAD Publication No-T/2005-3/389.

10. Erus B, Aktakke N. Impact of healthcare reforms on out-of-pocket health expenditures in Turkey for public insurees. Vol. Working Pa. Cairo-Egypt; 2010.

11. Hackler C. Health care reform in the United States. Heal Care Anal. 1993; 1: 5-13.

12. Adinolfi P. Barriers to reforming healthcare: The Italian case. Heal Care Anal. 2014; 22(1): 36-58.

13. Liaropoulos LL, Kaitelidou D. Surveys of the distributio n of freshwater crayfish (austropotamobius. Heal Care Anal. 1998; 6: 277-85.

14. Tatar M, Mollahaliloglu S, Sahin B, Aydin S, Maresso A, Hernández-Quevedo C. Turkey: health system review 2011. Health Syst Transit. 2011; 13(6): $1-186$.

15. Ilgun G, Sahin B. Investigating the opinions of employees working in family medicine about family medicine practice. Hacettepe Saglik Idaresi Derg. 2016; 19(2): 115-30.

16. Acar OK. Ministry of health organizations after health transformation program; quality analysis on Isparta river. MANAS J Soc Stud. 2018; 7(3): 703-22.

17. Adar S. Turkey: reform in social security. J Eur Soc Policy. 2007; 17(2): 167-8.

18. Istanbul Provincial Health Directorate. Organization chart. 2019. Available from: https://dosyaism.saglik.gov.tr/Resim/76569,teskilats emasijpg.png?0

19. Basol E, Isik A. Recent developments in health policy in Turkey: from health transformation program to present evaluation and some sugge*9stions. IAAOJ Soc Sci. 2015; 2(2): 1-26. Available from: http://iaaoj.com/index.php/sosyalbilimler/article/vie w/104

20. Turan AM. Türkiye'nin yeni yönetim düzeni: Cumhurbaşkanlığı Hükümet Sistemi. Soc Sci Res Journa. 2018; 7(3): 42-91.

21. OECD. OECD reviews of health care quality: Turkey 2014. OECD Publishing; 2014.

22. WHO. Successful health system reforms: the case of Turkey. Copenhagen-Denmark; 2012.

23. Sparkes SP, Bump JB, Reich MR. Political strategies for health reform in Turkey: extending veto point theory. Heal Syst Reform. 2015; 1(4): 263-75.

24. OECD. Health at a glance 2017: OECD indicators. Paris: OECD Publishing; 2017. Available from: https://www.oecd-ilibrary.org/social-issuesmigration-health/health-at-a-glance2015_health_glance-2015-en

25. Turkish Statistical Institute. Health expenditure statistics. Ankara-Turkey; 2019. Available from: http://tuik.gov.tr/PreTablo.do?alt_id=1084

26. WHO. World health statistics 2018: monitoring health for the SDGs, sustainable development goals. Geneva-Switzerland; 2018.

27. Sayim F. Health economics statistics and development of health expenditures in Turkey. Yalova Üniversitesi Sos Bilim Derg. 2017; 7(15): 1330.

28. Aydin N, Bakoglu R. Patient care costs in the state training and research hospitals in Istanbul in years 2000-2007. In: Procedia - Social and Behavioral Sciences. 2011. p. 1070-1089.

29. Ali Jadoo SA, Aljunid SM, Sulku SN, Nur AM. Turkish health system reform from the people perspective. BMC Health Serv Res. 2014; 14: 1-9. Available

from: http://www.biomedcentral.com/14726963/14/30\%0ARESEA

30. Bakan I, Buyukbese T, Ersahan B. The impact of total quality service (TQS) on healthcare and patient satisfaction: An empirical study of Turkish private and public hospitals. Int $\mathbf{J}$ Health Plann Manage. 2014; 29(3): 292-315.

31. Cesur R, Gunes PM, Tekin E, Ulker A. The value of socialized medicine: the impact of universal primary healthcare provision on birth and mortality rates in Turkey. Cambridge, MA; 2015.

32. Ministry of Health. Health statistics yearbook 2019. Ankara-Turkey: Ministry of Health; 2021. 182-184 p.

33. UNICEF. Decline in the under-5 mortality rate (U5MR) in Turkey: a case study (December 2009). Jelamschi L, De Ver Dye T, editors. 2010. 44 p.

34. World Bank. Health systems strengthening: lessons from the Turkish experience, 2009. Chakraborty S, editor. World Bank Knowl Br. 2009; 12. Available from:

http://scholar.google.co.uk/scholar?start=60\&q=alli 
ntitle:+Health+Systems+Strengthening\&hl=en\&as_ $\mathrm{sdt}=0,5 \# 9$

35. Hayran O. In terms of the success of health reforms, the decentralization-recentralization cycle and the situation in our country. J Biotechnol Strateg Heal Res. 2017; 1: 1-6.

36. Agartan TI. Health workforce policy and Turkey's health care reform. Health Policy (New York). 2015; 119: 1621-6.

37. Memişoğlu D. Bir kamu politikası analizi örneği: Sağlıkta Dönüşüm Programı. Yasam Derg. 2018; 34 62-93. Available from: https://dergipark.org.tr/tr/pub/yasamadergisi/issue/5 $4465 / 741347$

38. Yilmaz E, Gedikli EK. 2nd International 12th National Congress on Health and Hospital Administration. In: Sağlıkta Dönüşüm Programı ile Sağlık Bakanlığının değişen teşkilat yapısı. MuglaTurkey; 2018. p. 1715-28.

39. Erdem F, Atalay M. The effect of health transformation policies on the resident physicians' perception of the medical profession in Turkey. Int $\mathrm{J}$ Health Plann Manage. 2017; 32(2): 189-216.

40. Keskin Hİ. Türkiye'de Sağlıkta Dönüşüm Programı ve kamu hastanelerinin etkinliği. Akdeniz Üniversitesi İktisadi ve İdari Bilim Fakültesi Derg. 2018; 38: 124-50. 